811.163.41'366.584

https://doi.org/10.18485/sj.2019.24.1.38

\author{
ALEKSANDRA M. RADOVANOVIĆ ${ }^{*}$ \\ University of Kragujevac \\ Faculty of Hotel Management and Tourism \\ in Vrnjačka Banja
}

Оригинални научни рад Примљен: 11. 09. 2018. Прихваћен: 15. 01. 2019.

\title{
A CONTRIBUTION TO THE FUTURE TENSE DEBATE - A CASE STUDY FROM SERBIAN**
}

Considerable controversy surrounds the future tense, making its theoretical status the object of a long-standing debate. This paper intends to contribute to this line of research by providing evidence from a language widely accepted as having an uncontroversial future tense. It aims to pursue the following questions: whether Serbian has a clear-cut future tense and whether there is linguistic evidence to subsume this grammatical form under mood. To this end, the future tense in Serbian is scrutinised against the backdrop of the arguments presented in the debate on will. The theoretical account is supported by illustrative examples extracted from the contrastive sentential corpus compiled for the purposes of this research. The findings indicate that the Serbian future tense is not beyond dispute and point to the criticality of the conceptual argument. Also, the explanatory framework based on tense as an epistemic category (Lyons 1977) and modality as epistemic deixis (Frawley 1992) suggests that is to be subsumed under mood as the concepts of non-factivity, non-remoteness and irrealis modality clearly indicate its modal semantics.

Key words: the future tense, mood, modality, English, Serbian, epistemic.

*aleksandra.radovanovic@kg.ac.rs

** This paper is largely drawn from the doctoral dissertation entitled Modalna značenja sredstava za izražavanje futuralnosti u engleskom i srpskom jeziku (Modal Meanings of Futurity Expressions in English and Serbian) defended at the Faculty of Philology, Belgrade University, in 2016. 


\section{INTRODUCTION}

\subsection{The future tense controversy}

The majority of the world's languages have linguistic means of expressing three essential semantic-conceptual, or functional, categories: temporality, aspectuality and modality. Despite the significant differences in the repertoire of the available means in languages, tense, aspect and mood are the typical grammatical markers of temporality, aspectuality, and modality respectively. However, the nature of linguistic expression and language structure is characterised by great complexity. Firstly, there are intricate relations between the extra-linguistic concept of time and its linguistic counterpart, tense. As the ample evidence from the cross-linguistic research on TAM ${ }^{1}$ categories (Dahl 1985; Bybee, Dahl 1989; Bybee et al. 1991; Bybee et al. 1994) indicates, there is no 1:1 correspondence between grammatical categories and the semantic domains they tend to express. In addition, one semantic category may be expressed by a combination of grammatical markers. Hence, due to the great overlap and interplay between tense, aspect and mood/modality on more than one language level, it is not always easy to distinguish temporal, aspectual and modal meanings.

Tackling modality seems unavoidable in an in-depth semantic analysis of tense and aspect. Few scholars would challenge the claim that tense and modality are closely related (Langacker 2008: 300). The closest connection is, however, most commonly observed in the future time reference (FTR). The future tense is the grammatical expression of the future time which locates an event ${ }^{2}$ at a time later than the present moment. According to Reichenbach's (2005) theoretical framework, whereby all tenses can be described by ordering the relations of three locations in time (E - the point of event, $\mathrm{S}$ - the point of speech and R-the point of reference) on a time-line, the usage of the future tense in English is capable of two interpretations, neither of which can be taken as the prevalent or correct one (Reichenbach 2005: 76). Typically, it has the sequence $S-R, E^{3}$ when a future event is viewed without any reference to the present state, whereas the alternative interpretation in the form S,R-E conveys a present perspective of the events (Reichenbach 2005: 76). In addition, reliance on the principles of symbolic logic is not always possible due to the historical, i.e. modal, origin of this tense (Reichenbach 2005: 78).

Consequently, considerable controversy surrounds the future tense, making its theoretical status the object of a long-standing debate that is essentially the is-

${ }^{1}$ In this line of research, the TAM category has been established as an integrated super-category that encompasses the three semantic domains marked on the verb (tense-aspect-mood/modality).

${ }^{2}$ Following Palmer (1986), throughout the paper, the term event is used as a synonym for various other terms such as action, situation, state, state of affairs, etc.

${ }^{3}$ Dashes are used to represent an interval of time, and commas for representing simultaneity. 
sue of „whether such a category is justified in linguistic theory in the first place, as a tense" (Comrie 1985: 43). Concentrated on (dis)favouring the existence of the future tense as a formal category, researchers have investigated the possibility of delimiting the FTR and modality by giving prominence to either temporal or modal values in the semantics of grammatical markers (e.g. Lyons 1977; Comrie 1985). The debate, in fact, has arisen and mostly revolved around the perennial question: Does English have a Future Tense? A great deal of research has sought to determine the basic meaning and the dominant language function of will and offer its appropriate classification within the grammatical system of English (e.g. Sarkar 1998; Salkie 2010a; 2010b).

\subsection{The reasons behind the study, aims and methods}

Although the status of will still lacks a definite conclusive answer, the arguments presented in the debate have in turn generated interest in the FTR in other languages. The debate has taken hold in both contrastive (e.g. Salkie 2010b) and theoretical studies (e.g. Comrie 1985) and arguments for the modal treatment of the future tenses in other languages have also been proposed (see Hilpert 2008: 4). This is not the case with Serbian, however, as the future tense has not become a matter of controversy in our linguistic literature (Piper et al. 2005: 434). While the tense form in English has drawn considerable attention, its equivalent form in a typologically related language ${ }^{4}$ has not become the focus of similar theoretical considerations, with the exception of a few recent studies (Trbojević-Milošević 2004; Radovanović 2017a,b).

Therefore, the current study intends to tackle a relatively untrodden field of research and investigate the future tense in Serbian in light of the controversy over the concept of the future tense. The questions we pursue here are: whether Serbian has a clear-cut future tense and whether there is linguistic evidence to subsume this grammatical form under mood, as previously proposed by Trbojević-Milošević (2004). To this end, the future tense is subjected to scrutiny against the arguments presented in the debate, which are formulated on the basis of the commonly discussed objections against the view of will as a future tense auxiliary (Lyons 1977; Comrie 1985; Sarkar 1998; Salkie 2010a, 2010b). Since the perplexing question about the future tense can only be answered by an investigation of the grammatical expressions of FTR across a number of languages (Comrie 1985: 44), this study could contribute to the ongoing debate by providing evidence from a language which is commonly believed to have an uncontroversial future tense. Also, it could offer certain insights which may serve to advance our understanding of the investigated

\footnotetext{
${ }^{4}$ Numerous contrastive studies testify to the typological relatedness between English and Serbian (e.g. Trbojević-Milošević 2004; Radovanović 2017b).
} 
verb form and contribute to the field of the meaning and use of verb forms in Serbian as one of the most complex linguistic issues (Simić 2017).

The descriptive analysis focuses on the use of the investigated tense in simple sentences or independent clauses. The theoretical account is supported by illustrative examples extracted from the contrastive sentential corpus compiled for the purposes of this research. It comprises excerpts from two novels (written by I. McEwan and K. Ishiguro) and their published Serbian translations. ${ }^{5}$ The English novels were searched for the relevant instances of will, and their translations were then excerpted from the novels in Serbian, which resulted in the corpus containing 187 examples in both languages. The study builds on previous research which has challenged the concept of the indicative future tense (Trbojević-Milošević 2004) and argued for its dual semantics (Radovanović 2017a). It takes an eclectic approach and relies on the theoretical tools from the relevant theoretical studies on tense and modality from various linguistic fields: the philosophy of language (Jespersen 1924; Lyons 1997), language typology (Dahl 1985; Palmer 1986; ${ }^{2} 2001$; Frawley 1992; Bybee et al. 1994; Timberlake 22007), and cognitive linguistics (Langacker 2008).

Following a brief review of the approaches to the future tense in Serbian philological tradition, in the central part of the study, the main arguments against this grammatical category in English are presented and used as a backdrop to scrutinise the Serbian future tense. The findings are summarised in the conclusion.

\section{THE FUTURE TENSE IN SERBIAN PHILOLOGICAL TRADITION}

In Serbian philological thought, the treatment of tenses subscribes to the widely adopted convention of the three times-three tense system ${ }^{6}$ and rests on the theoretical foundations set by academicians A. Belić and M. Stevanović. Therefore, indicative, relative and modus (mode) are used as theoretical tools to account for all the functions and meanings of Serbian tenses. In this line of thought, also reflected in Serbian descriptive and normative grammatical tradition (e.g. Klajn 2005, Piper et al. 2005), the future tense is regarded as a flective tense form whose primary function is to express events that will occur after the speech time or the moment referred to (Stevanović 1967: 132). Used for FTR, it refers to those actions which almost exclusively belong to the syntactic indicative (Piper et al. 2005: 434). The indicative future expresses a declarative statement of a future event realisation without any indications of personal attitude whatsoever as in 1b), i.e. it is used

${ }^{5}$ Bibliographical descriptions of the textual material, along with the abbreviations used in this study, are provided in the section Sources.

${ }^{6}$ In Serbian, this is reflected in the terminology, as vreme denotes both the extralinguistic concept of time and a grammatical device. 
for referential future actions, whereas the relative future expresses an event that is future in relation to some other past or future event.

1a) It'll be on the next news, Dad. Half four. (M SAT)

1b) Objaviće, tata, u sledećim vestima. Pola pet. (M SUB 34)

The indicative and relative are the primary devices for the temporal determination of a predication (Piper et al. 2005: 345) and for expressing temporal relations and, as such, they substantially differ from modus. Modus subsumes all the modal uses of tenses that are generally based on the semantics of the verbal mood, and is basically a semantically defined morpho-syntactic category. Despite the different approaches to the modal uses, scholars maintain that temporal meanings constitute the basic semantics of the future tense, even in some of its non-temporal functions. Serbian linguists, however, do not neglect the specific characteristics of the future time described in 3.1., frequently pointing to it as a major obstacle to clearly and conclusively distinguishing temporal from modal functions (e.g. Stevanović 1967: 132; Milošević 1970: 74; Grković-Mejdžor 2012: 84).

\section{THE FUTURE TENSE IN LIGHT OF THE ARGUMENTS IN THE DEBATE ON WILL}

\subsection{The conceptual argument}

Aristotle pointed to the notorious fact that the future differs epistemologically and ontologically from the present and the past (Dahl 1985: 103), which has placed the future as an important area of concern for philosophers and logicians. Hence, the issues of whether the future is determined and settled, if the truth-values of propositions about this temporal domain can be determined and how a future fact should be treated have received significant attention and directly influenced linguistic research. Reasonably, the major influence is evident in the field of language philosophy (Jespersen 1924; Lyons 1977).

We can experience the present and past either directly or indirectly, whereas „the future cannot yet be experienced even indirectly because it has not yet happened - we can only project, speculate or imagine" (Langacker 2008: 300). Also, the future is speculative in that any prediction made about the future can be altered by intervening events, including our own conscious intervention (Comrie 1985: 43). As Jespersen (1924: 265) points out, ,we can assert nothing with regard to a future time but mere suppositions and surmises". Given the lack of knowledge and certainty of future events, Lyons (1977: 677) concludes that the FTR necessarily includes prediction or some related modal notion. Considerable evidence derived from empirical research carried out within language typology (Bybee et al. 1991; 
Dahl 1985; Bybee et al. 1994; Timberlake 22007) supports the view of FTR as never being a purely temporal concept.

Timberlake's (22007: 306) claim that ,any statement about the future is an assessment of modality - of the possibility of an event happening at some time later than the speech time" is illustrative of the prevailing line of thought. It also complies with the branching worlds model since ,the future always allows for branching alternatives: at any time there are at least two futures that are compatible with that situation" (Timberlake 22007: 307). This model illustrates the future as an open domain with several alternatives in the possible worlds following a present moment.

\subsection{The formal argument}

According to Comrie (1985: 9), tense is the ,grammaticalised expression of location in time". There is, however, the disputed issue closely related to the formal constraints on tenses and the formal constraints on verb forms to be regarded as tenses on the morpho(syntactic) level. FTR expressions seem most problematic in this respect. Cross-linguistically, the FTR is less consistently marked than the past time reference (Dahl, 1985: 105-109) and futures are unique among the major tense and aspect categories since they are evenly split between morphologically bound and periphrastic expressions (Bybee, Dahl, 1989: 90). Therefore, Lyons argues for dichotomous tense systems since the most frequent grammatical distinction made in the vast majority of languages is that between past and non-past (Lyons 1977: 678 ; 1995: 314). This position is frequently held in the descriptive grammars of English (e.g. Quirk et al. 1985; Huddleston, Pullum 2002).

Unlike English, Serbian is a flective language with a very rich tense system that does not have a clear grammatical past/non-past distinction. In Serbian, tense as a morphosyntactic category also includes periphrastic tenses made compounds by means of auxiliary verbs. Nevertheless, the future tense has a unique status as the only member of the tense system with twofold realisations. According to the prescriptive rules, it is the periphrastic tense made a compound by the auxiliary hteti in a clitic form and the infinitive of the lexical full verb, but which is also partially the analytic tense (Klajn 2005: 114-119). In the affirmative, it can occur either as a flective $1 \mathrm{~b}$ ) or a periphrastic $2 \mathrm{~b}$ ) form.

2a) This is how it will be in his seventies. (M SAT)

2b) Tako će biti kad pređe sedamdesetu. (M SUB 39)

Hteti as a fully conjugated form occurs mainly in negative and interrogative contexts, as 3b) and 4b) illustrate respectively. As can be seen from 4b) and 5b), question forms also have twofold realisations. 
3a) Nothing will stop him from falling asleep. (M SAT)

3b) Ništa ga neće sprečiti da zaspi. (M SUB 51)

4a) Will it be obvious that there was nothing to be done...? (M SAT)

4b) Hoće li biti očigledno da se ništa nije moglo učiniti ...? (M SUB 26)

5a) ... will it seem negligent not to have called the emergency services? (M SAT)

5b) ... da li će izgledati kao nemar to što nije pozvao hitnu službu? (M SUB 26)

In addition, the increasing layering of the tense is also noticeable, so that the synchronic coexistence of the variant containing $d a+$ present instead of the infinitive, futuroid in Simić's designation (2009), is not uncommon ${ }^{7}$ (Stevanović 1967: 44). To illustrate, a hypothetical translation of example 2a) could be:

2c) Tako će da bude kad pređe sedamdesetu.

Despite these morphosyntactic complexities, the Serbian future tense bears a significant similarity to its English counterpart. This is primarily related to the auxiliary verb as both languages employ a verb with the original volitional meaning (wanting or willing something to happen). This dynamic modality notion is a subject-oriented modal meaning which refers to the potentiality of an activity resulting from the subject's willingness/readiness. From a grammatical point of view, hteti is a modal verb (Stevanović 1967: 42) which conveys dynamic modality. Typically, it is considered a desemantised auxiliary verb which has become a mere morphological device that forms part of the indicative tense (e.g. Milošević 1970: 73).

\subsection{The diachronic argument}

The evidence on the origin and development of FTR expressions provides further support to the claim that these are a matter of modality. The future tenses have been created from word-forms or phrases that were originally used to express various kinds of non-factivity (Lyons 1977: 816) typically including agent-oriented modalities, a construction meaning movement towards a goal, a verb meaning to owe or to be obliged, other verbal sources (be, become), temporal adverbs as well as markers of the progressive aspect (Bybee, Dahl 1989; Bybee et al. 1994; Dahl 2010).

Once developed, these expressions have undergone the process of grammaticalisation accompanied by a concurrent semantic change (Kramer 1998: 407). Morphological boundness, which refers to the ,integration into the grammatical system of a language" (Comrie 1985: 10), is taken as the foremost parameter of grammaticalisation. Its degree may be considered on the basis of the proposed cline of grammaticality:

${ }^{7}$ The earlier philologists also noted the use of this verb form (see Simić 2017). 


\section{content item $\rightarrow$ grammatical word $\rightarrow$ clitic $\rightarrow$ affix (Kramer 1998: 408)}

The future tense in modern Serbian developed from the Slavic modal verb xotéti to which hteti is clearly related. By applying a set of parameters based on various factors including decategorisation, a lack of inflection for a person or tense, a lack of syntactic antonymy, and semantic features, as proposed by Kramer (1998), its level of grammaticalisation can be evaluated as follows:

1) hteti is marked for person and number and can occur as a fully grammaticalised particle attached to the main verb, but it does not need to be connected to it (cf. 1b) and 2b));

2) given the two coexistent future forms, hteti can syntactically function either as a clitic or a full verb;

3) when the future tense does not occur in the analytical form, other words can occur between the auxiliary and the main verb (see 14b));

4) hteti also functions as a modal verb that encodes non-epistemic modality; and

5) in the negative form, hteti generally retains its modal meaning.

Thus, the Serbian future tense is not fully grammaticalised and represents the first of the three stages of the development of the future tenses in Balkan Slavic languages (Tomić 2004).

\subsection{The pluralism of FTR expressions}

Generally, FTR is a heterogeneous area with numerous grammatical morphosyntactic expressions (Bybee et al. 1994: 243). In Serbian, along with various lexical and pragmatic expressions, different tenses other than the future tense may be employed for the FTR such as: the present tense (either its modal usage (Stevanović 1967) or a temporal transformation/transposition) (Piper et al. 2005)), the aorist tense, the perfect (past) tense (the future past (Piper et al. 2005) or the modal past tense (Stevanović 1967)), and future II (Kovačević 2008). Of these, our corpus reveals only the present tense, as in $6 \mathrm{~b}$ ), as a semantic equivalent of the English future tense.

6a) ... I will buy you a meal in a good Iraqi restaurant in London. (M SAT)

6b) ... vodim vas na večeru u neki dobar irački restoran u Londonu. (M SUB 61)

\subsection{The polyfunctionality of the future tense}

Given their historical development, future forms are often polyfunctional or polysemous, and the FTR is only one of their uses (Bybee et al. 1994: 243-244). This also holds true for the Serbian future tense. In 7b), as the English present tense equivalent, it expresses generic meaning, whereas in $8 b$ ) it is readily interpretable 
in terms of habitual meaning. The negative context in $9 \mathrm{~b}$ ) gives rise to the clearest and strongest dynamic interpretation as non-volition is almost equivalent to refusal. In both $9 a$ ) and 9b) the future forms refer to the subject's present disposition.

7a) There are always crises... (M SAT)

7b) Krize će uvek postojati ... (M SUB 72)

8a) Even when the rest of the café is extremely busy, the proprietor will see to it we don't get crowded out or disturbed. ( I UNC)

8b) Čak kada je velika gužva u ostalom delu kafea, vlasnik će se pobrinuti da nam ne bude tesno i da nas niko ne uznemirava. (I BU 16)

9a) ... you won't stand by what you believe. (M SAT)

9b) ... nećeš da staneš iza svog uverenja. (M SUB 175)

\section{DISCUSSION}

The arguments discussed in sections 3.2. to 3.5. may be considered inconclusive and unconvincing by the proponents of the future tense. Firstly, based on the formal argument, it is unwarranted to claim that it should not be considered a tense as only the present tense is an inflectional verb form of the Serbian tense system. A similar conclusion can be drawn based on its level of grammaticalisation since the fully grammaticalised form could hardly be expected. Morphologically marked forms appear in the late stages of grammaticalisation and future tenses are a comparatively recent development in many Indo-European languages (Lyons 1977: 677), which is indicated by the semantic transparency of the grammaticalised elements (Grković-Mejdžor 2012: 85).

Secondly, the diachronic relation between the future tense and the modal expression of desiderativity from which it derived say nothing of its synchronic status (Comrie 1985: 46). However, its different forms of realisation can be crucial in ascribing modal meanings. Namely, due to the semantic contribution of the auxiliary, the negative and interrogative sentences remain ambiguous between the futurity and dynamic modal meaning. This particularly holds true for the instances with the $1^{\text {st }}$ person subjects such as $9 \mathrm{~b}$ ) and $10 \mathrm{~b}$ ) in which the volitional meaning tends to be more salient. Since volition can be accounted for deontically, an interrogative with $2^{\text {nd }}$ person subjects, as in $11 \mathrm{~b}$ ), questions volition and indirectly conveys a request to perform a future action, thus allowing for the interpretation in terms of pragmatic implicature.

10a) We won't do a thing about it. (M SAT)

10b) Nećemo te goniti. (M SUB 202)

11a) Will you do it for me and Bruno? (I UNC)

11b) Hoćete li učiniti to za mene i Bruna? (I BU 37) 
Further, despite not being in accordance with the normative rules, the $d a+$ present clause may appear in the complement position of the auxiliary (e.g. Piper et al. 2005: 327). As the type of complement is the proposed criterion for determining modal or tense function (Stevanović 1967: 44), the modality import becomes more prominent as in $9 \mathrm{~b}$ ). The treatment of this complement as a subjunctive construction (e.g. Tomić 2004) clearly points to the non-temporal function. This explains why futuroids are more readily ascribed modal meanings (Simić 2009: 53), as 9b) shows. Hence, the different syntactic realisations of the future tense are not of the same semantic value.

Thirdly, despite the ostensible richness of the FTR in Serbian, the future tense is by far the most frequently used device. Its frequency of occurrence is followed by that of the present tense which is characterised by temporal polyvalence. The past tense and aorist are used for imminent events far less commonly and only under certain contextual conditions. As for future II, which is primarily used in dependent clauses, the co-textual features limit its independent use, i.e. the presence of the modal adverb možda (maybe) (Kovačević 2008).

As regards the objection regarding polysemy, it is easily overcome as irrelevant due to the prevailing position that all tenses, in addition to their basic meanings, also have secondary derivative meanings (Comrie 1985: 18). As shown by examples $7 a)-9 b$ ), the future tense does not uniquely refer to the future and can render non-epistemic modal meanings. Further, in English, it expresses the assumptive judgment that indicates an inference from what is generally known (Palmer ${ }^{2} 2001$ : 24-30) as in 12a). Since in Serbian, the future tense of biti can refer to the present or the past with the clear function of an epistemic modal, 12c) may be suggested as an alternative translation for 12a). In this case, biće analogously to will conveys epistemic, i.e. predictability meaning, and expresses the speaker's level of commitment towards the proposition (see Radovanović 2017b).

12a) Jay Strauss will be on court, warming up the ball. (M SAT)

12b) Džej Straus je sigurno već na terenu, zagreva lopticu. (M SUB 84)

12c) Biće da je Džej Straus na terenu, zagreva lopticu.

However, these clearly modal uses of the future tense, which have also been analysed as pragmatic inferences from a basic future time meaning (Comrie 1985; Salkie 2010a), are not at issue. Whether the future indicative tense is modally nuanced to the extent to be treated as mood is what is at stake. For instance, 13b) seems to allow for a twofold interpretation when extracted from the context which would provide the temporal reference. Based on a native speaker's intuition, we are more inclined to interpret it in terms of willingness, as an intermediate volition conveying the idea of intention, i.e. a commissive speech act (Radovanović 2017b).

13a) I'll do anything you want. (M SAT)

13b) Uradiću sve što želiš. (M SUB 207) 
This leads us to the previously noted discrepancies and inconstancies regarding the future indicative (Trbojević-Milošević 2004; Radovanović 2017a). The future tense refers to unrealised events that are not connected with objective or realised reality. As verbal mood is used for unrealised or uncertainly realised reality, the future tense should, thus, be included in this category. Also, the realisation of future events viewed in terms of certainty is fundamental for the indicative future (e.g. Stevanović 1967: 136). Reasonably, one can never be certain of the future, which in turn entails the disputable philosophical issue of the future fact. Neither the objective certainty nor the objective reality of future events can be established. Certainty is, in fact, related to the linguistic reality based on the speaker's evaluation. Since certainty, otherwise regarded a modal notion by Stevanović (1967), on the part of the speaker is only an attitude, the future tense should be included in mood.

This line of reasoning is clearly based on the conceptual argument, and for that matter, the arguments based on the grammatical structure of Serbian can easily be dismissed as not decisive. The discussion on the future tense in Serbian, in fact, boils down to the very issue of the status of the future tense in general linguistic theory. In light of the conceptual argument, the following can be regarded as critical for future tense semantics. Firstly, given its inherent predictive nature, the FTR may be analysed in terms of modal notions ranging from mere supposition to certainty, making the relationship between subjective epistemic modality and the FTR obvious enough (Lyons 1977: 816). In this regard, future tense utterances express various levels of the speaker's epistemic commitment towards the truthfulness of the expressed proposition (Radovanović 2017b). As certainty, the highest point on the epistemic scale, parallels epistemic necessity in logical terms, the following example may be seen in terms of objective epistemic necessity.

14a) And then, he, Henry, will turn fifty and give up squash and marathons... (M SAT)

14b) A onda će on, Henri, napuniti pedeset godina i ostaviti skvoš i maratone... (M SUB 260)

Following Lyons's (1977: 797-804) discussion, the objective possibility, or the degree of probability of the truth of the proposition can be mathematically calculated. The objectively modalised utterance has an unqualified I-say-so component, while the it-is-so component is qualified with respect to a certain degree of probability, which, if quantifiable, ranges between 1 and 0 (Lyons 1977: 800). As regards 14a,b), the speaker draws a logical conclusion based on the objective indicators in accordance with knowledge about the general features of the world, which are the premises of the conclusion. The objective possibility is of degree 1 as, based on the available evidence which is the objectively measurable fact, the speaker considers the truth of the proposition as an epistemically necessary truth in all possible worlds $w_{1}, w_{2}, w_{3}$ following the time of speech. 
This leads us to the non-factivity or non-factuality of future tense utterances. Non-factivity, the term frequently used in philosophical literature in relation to the status of the proposition, results from epistemic modalisation. From the standpoint of a linguist, future tense utterances can be ascribed non-factuality as indicating the opposition to reality. Both terms clearly point to future events as non-facts. As they do not (at least not yet) form part of reality, they are only possibilities that may or may not hold real or true at a future point, i.e. in a possible world.

Assigning non-factuality clearly subsumes the future tense under modality, the semantic category related to the factual status of the proposition (e.g. Frawley 1992). In this respect, the view of tense as an epistemic category serves as an adequate explanatory framework, as pointed out by Trbojević-Milošević (2004). According to Lyons (1977: 819-823), tense and modality are intertwined to the extent that tense can be regarded as a specific kind of modality, whereas modality is closely related to deixis. Thus, the deictic distinction of temporal remoteness overlaps with modal remoteness. On these grounds, what is commonly treated as an opposition of tense (past/non-past) should be more properly regarded as a particular case of the remote/non-remote distinction (Lyons 1977: 819). Under this interpretation, the future tense is considered to be the product of non-remoteness and non-factivity (Lyons 1977: 820).

The view that the choice of tense depends more on the epistemic status the speaker wishes to convey rather than the temporal location of the event has been further elaborated by Frawley (1992). Frawley (1992) considers modality as a kind of knowledge-based epistemic deixis defined on the basis of the opposition of actual worlds, realis, and nonactual worlds, irrealis. Modality encodes the comparison of an expressed world, the state of affairs in the asserted proposition, with a reference world, the actual world of speech. The expressed world is the modal equivalent of the deictic located point, whereas the reference world is the modal counterpart of the temporal reference point, the here-and-now (Frawley 1992: 387). Realis, or actual modality, refers to those instances when the reference world coincides with the expressed world, whereas irrealis, or non-actual modality, deals with those when the reference world fails to coincide with the expressed world (Frawley 1992: 388). The factual status of the proposition results from the extent to which the two epistemic deictic points diverge. As this distinction overlaps with tense, it may be argued that realis modality is associated with facts, either in the present or past, whereas irrealis modality is associated with imagined, future, contrary, or imposed events. Hence, the tense system can be seen in terms of the binary modality distinction: realis modality covers the past and present tenses, i.e. the indicative which is related to facts, whereas irrealis modality subsumes FTR expressions. 


\section{CONCLUSION}

The study has addressed the controversy over the future tense by focusing on the possible conflict between the future tense and modality in the Serbian future tense. The analysis has provided linguistic evidence for the following claims on this form in Serbian:

- It is not a fully grammaticalised verb form and has complex morphosyntactic realisations, which makes it a unique member of the tense system in Serbian;

- It derived from an expression of dynamic modality, which makes it ambiguous in terms of temporal or modal interpretation, especially in negative and interrogative contexts, with the $1^{\text {st }}$ person subjects in particular;

- It is neither the only nor the obligatory grammatical device for the FTR in Serbian;

- It is used in a range of non-factive contexts, including the FTR, which arguably makes it semantically different from the grammatical markers for past and present time reference. Therefore, it syntactically and semantically differs from the other members of the Serbian tense-system; and

- The instances of the indicative future tense allow for the interpretation in either dynamic or epistemic (subjective or objective) modality. In all of its uses, it expresses the level of commitment on the part of the speaker/ subject.

These findings reveal that the future tense in Serbian is far from being beyond dispute and are in line with Lyons's (1977: 677) claim that „the so-called future tense of Indo-European languages ... is partly temporal and partly modal". The answer to the question of whether it is to be subsumed under tense or mood is not entirely conclusive as the arguments based on the morphosyntactic and semantic features can easily be dismissed as not decisive. On the other hand, they indubitably indicate that there is no precise borderline between the future tense and modality so that the possibility of subsuming the FTR under modus, i.e. mood, in Serbian is left open based on the four arguments discussed. The conceptual argument is of critical importance. The study has also shown that the taken position is heavily dependent on the theoretical framework. If the explanatory framework is based on the views of tense as an epistemic category (Lyons 1977) and modality as epistemic deixis (Frawley 1992), the future tense in Serbian is to be included into the mood category as the concepts of non-remoteness, non-factivity and irrealis modality clearly indicate its modal semantics. Therefore, this study has corroborated the previous proposal by Trbojević-Milošević (2004). 


\section{SOURCES}

I BU - Išiguro Kazuo. Bez utehe. Preveo Nenad Tomović. Beograd: Plato. 2003.

I UNC - Ishiguro Kazuo Unconsolded. $<$ http://www.bgcapp.com/books/download/ asin $=0679735879 \&$ type $=$ stream. $>10 / 11 / 2016$

M SAT - McEwan Ian. Saturday. $<$ http://ebookscart.com/saturday-by-ian-mcewannovel-pdf-download.> 16/10/2017

M SUB - Makjuan Ijan. Subota. Prevela Arijana Božović. Beograd: Paideia. 2006.

\section{REFERENCES}

Bybee et al. 1991: J. Bybee, R. D. Perkins, W. Pagliuca, Back to the future, in: E. C. Traugott, B. Heine (eds.), Approaches to grammaticalization: Focus on types of grammatical markers, Vol. II, Amsterdam: Paul Benjamins Publishing Company, 17-59.

Bybee et al. 1994: J. Bybee, R. D. Perkins, W. Pagliuca, The evolution of grammar. Tense, aspect, and modality in the languages of the world, Chicago and London: University of Chicago Press.

Bybee, Dahl 1989: J. Bybee, Ö. Dahl, The creation of tense and aspect systems in the languages of the World, Studies in Language, 13 (1), 51-103.

Comrie 1985: B. Comrie, Tense, Cambridge: Cambridge University Press.

Dahl 1985: Ö. Dahl, Tense and Aspect Systems, Oxford: Basil Blackwell.

Dahl 2010: Ö. Dahl, Tense and Aspect in the Languages of Europe, Berlin: Mouton de Gruyter.

Frawley 1992: W. Frawley, Linguistic Semantics, Hillsdale, New Jersey, Hove and London: Lawrence Erlbaum Associates.

Grković-Mejdžor 2012: Ј. Грковић-Мејџор, Развој футура у старосрпском језику, Зборник Матице српске за филологију и лингвистику, LV/1, Нови Сад, 83-104.

Hilpert 2008: M. Hilpert, Germanic future constructions: A usage-based approach to language change (Vol. 7), John Benjamins Publishing.

Huddleston, Pullum 2002: R. Huddleston, G. K. Pullum, The Cambridge Grammar of the English Language, Cambridge: Cambridge University Press.

Jespersen 1924: O. Jespersen, The philosophy of grammar, London: Allen and Unwin Brothers Ltd. 
Klajn 2005: I. Klajn, Gramatika srpskog jezika, Beograd: Zavod za udžbenike i nastavna sredstva.

Kovačević, М. 2008: М. Ковачевић, Конкурентност двају футура и перфективног презента у савременом српском језику, Зборник Матище српске за славистику, 73, Нови Сад, 195-211.

Kramer 1998: C. Kramer, Negation and Grammaticalization of Have and Want Futures in Bulgarian and Macedonian, Canadian Slavonic Papers, International Congress of Slavists. Vol. 39, Nos. 3-4, 407-436.

Langacker 2008: R. W. Langacker, Cognitive Grammar: A Basic Introduction, Oxford: Oxford University Press.

Lyons 1977: J. Lyons, Semantics, Vol 2, Cambridge: Cambridge University Press.

Lyons 1995: J. Lyons, Linguistic Semantics: An Introduction, Cambridge: Cambridge University Press.

Milošević 1970: K. Milošević, Futur II $i$ sinonimski oblici u savremenom srpskohrvatskom književnom jeziku, Sarajevo: ANUBIH.

Palmer 1986, 22001: F. R. Palmer, Mood and Modality, Cambridge and New York: Cambridge University Press.

Piper et al. 2005: П. Пипер, И. Антонић, В. Ружић, С. Танасић, Љ. Поповић, Б. Тошовић, Синтакса савременога сриског језика. Проста реченица (ред. Милка Ивић), Београд: Институт за српски језик САНУ - Београдска књига - Матица српска.

Quirk et al. 1985: R. Quirk, S. Greenbaum, G. Leech, J. Svartvik, A Comprehensive Grammar of the English Language, London and New York: Longman Group Limited.

Radovanović 2017a: А. М. Радовановић, Семантички статус футура I - временска или модална категорија. Зборник радова Филозофског факултета Универзитета у Приштини, XLVII (1)/2017, 235-254.

Radovanović 2017b: А. М. Радовановић, Футур I - фазилингвистичка категорија. Наслеђе, Крагујевац, 14 (38): 125-139.

Reichenbach 2005: H. Reichenbach, The tenses of verbs, in: I. Mani, J. Pustejovsky \& R. Gaizauskas (Eds.), The language of time: A reader, Oxford, UK: Oxford University Press, 71-78. (Original work published 1947).

Salkie 2010a: R. Salkie, Will: Tense or modal or both, English Language and Linguistics, 14, 187-215. 
Salkie 2010b: R. Salkie, Facing the future together: French and English in contrast. $<$ http://dx.doi.org/10.1051/cmlf/2010157> 23/08/2011.

Sarkar 1998: A. Sarkar, The Conflict Between Future Tense and Modality: The Case of Will in English, University of Pennsylvania Working Papers in Linguistics, vol. 5, no. 2, 91-117.

Simić 2009: Р. Симић, Нормативни и употребни статус футуроида ЋУ/ЋЕШ...+ ДА + ПРЕЗЕНТ, Научни састанак слависта у Вукове дане, 38 (1), $51-55$.

Simić 2017: Р. Симић, Учење старијих филолога о употреби и значењу глаголских временских облика - и његов значај, Српски језик-студије српске и словенске, XXII, 335-360.

Stevanović 1967: М. Стевановић, Функиије и значења глаголских времена, Београд: Научно дело.

Timberlake 2007: A. Timberlake, Aspect, tense, mood, in: T. Shopen, (ed.). Language typology and syntactic description, grammatical categories and the lexicon, Vol. III, Cambridge: Cambridge University Press, 280-333.

Tomić 2004: M. O. Tomić, The Syntax of the Balkan Slavic Future Tenses, Lingua, $114,517-542$.

Trbojević Milošević 2004: I. Trbojević-Milošević, Modalnost, sud, iskaz, Beograd: Filološki fakultet.

\section{ПРИЛОГ РАСПРАВИ О ФУТУРУ - СТУДИЈА СЛУЧАЈА ИЗ СРПСКОГ ЈЕЗИКА}

\section{Резиме}

Бројне су контроверзе око изражавања будућности, те је статус футура као граматичке категорије предмет дуготрајне дебате. Намера рада је да пружи допринос овом правцу истраживања на основу анализе из језика који је типолошки сличан енглеском, а за који се обично сматра да поседује футур као неоспорну временску категорију. Рад намерава да истражи одговоре на следећа питања: да ли српски језик поседује јасну категорију будућег времена глагола и да ли постоје језички докази за сврставање овог глаголског облика у домен модалности. На основу дескриптивно-контрастивног метода, примењујући еклектички приступ, у раду се анализира реализација футура у српском језику на енглеско-српском реченичном корпусу састављеном за потребе овог истраживања. Глаголски облик у фокусу рада сагледава се у светлу аргумената понуђених у дискусији о глаголу will у енглеском језику. Иако налази на основу разматрања формалног и дијахронијског аргумента, плурализма средстава за 
изражавање будућности и полифункционалности глаголског времена не пружају дефинитивне одговоре, недвосмислено указују на блиско преплитање будућег времена и модалности. Дакле, концептуални аргумент је од пресудног значаја. Експланаторни оквир у коме се глаголско време сагледава као епистемичка категорија, а модалност као епистемичка деикса, јасно указује да футур треба обухватити модалном категоријом, јер се овај глаголски облик доводи у везу са концептима не-фактивности, неудаљености и иреалис модалношћу.

Кључне речи: футур, глаголски начин, енглески језик, српски језик, епистемички.

Александра М. Радовановић 